Check for updates

Cite this: RSC Adv., 2019, 9, 27042

\title{
Effectiveness of metal oxide catalysts for the degradation of 1,4-dioxane $\uparrow$
}

\author{
Kimberly N. Heck, (D) a Yehong Wang, (DD ${ }^{\mathrm{b}}$ Gang Wu, ${ }^{\mathrm{c}}$ Feng Wang, (D) ${ }^{\mathrm{b}}$ Ah-Lim Tsai, ${ }^{\mathrm{c}}$ \\ David T. Adamson ${ }^{d}$ and Michael S. Wong (D) *aefgh
}

1,4-dioxane, commonly used as a solvent stabilizer and industrial solvent, is an environmental contaminant and probable carcinogen. In this study, we explored the concept of using metal oxides to activate $\mathrm{H}_{2} \mathrm{O}_{2}$ catalytically at neutral $\mathrm{pH}$ in the dark for 1,4-dioxane degradation. Based on batch kinetics measurements, materials that displayed the most suitable characteristics (high 1,4-dioxane degradation activity and high $\mathrm{H}_{2} \mathrm{O}_{2}$ consumption efficiency) were $\mathrm{ZrO}_{2}, \mathrm{WO}_{x} / \mathrm{ZrO}_{2}$, and $\mathrm{CuO}$. In contrast, materials like $\mathrm{TiO}_{2}, \mathrm{WO}_{3}$, and aluminosilicate zeolite $\mathrm{Y}$ exhibited both low 1,4-dioxane degradation and $\mathrm{H}_{2} \mathrm{O}_{2}$ consumption activities. Other materials (e.g., $\mathrm{Fe}_{2} \mathrm{O}_{3}$ and $\mathrm{CeO}_{2}$ ) consumed $\mathrm{H}_{2} \mathrm{O}_{2}$ rapidly, however 1,4dioxane degradation was negligible. The supported metal oxide $\mathrm{WO}_{x} / \mathrm{ZrO}_{2}$ was the most active for 1,4dioxane degradation and had higher $\mathrm{H}_{2} \mathrm{O}_{2}$ consumption efficiency compared to $\mathrm{ZrO}_{2}$. In situ acetonitrile poisoning and FTIR spectroscopy results indicate different surface acid sites for 1,4-dioxane and $\mathrm{H}_{2} \mathrm{O}_{2}$ adsorption and reaction. Electron paramagnetic resonance measurements indicate that $\mathrm{H}_{2} \mathrm{O}_{2}$ forms hydroxyl radicals $\left({ }^{\circ} \mathrm{OH}\right)$ in the presence of $\mathrm{CuO}$, and unusually, forms superoxide/peroxyl radicals $\left({ }^{\circ} \mathrm{O}_{2}{ }^{-}\right)$ in the presence of $\mathrm{WO}_{x} / \mathrm{ZrO}_{2}$. The identified material properties suggest metal oxides $/ \mathrm{H}_{2} \mathrm{O}_{2}$ as a potential advanced oxidation process in the treatment of 1,4-dioxane and other recalcitrant organic compounds.

Received 2nd July 2019

Accepted 14th August 2019

DOI: $10.1039 /$ c9ra05007h

rsc.li/rsc-advances oxidative processes $\left(\mathrm{UV} / \mathrm{H}_{2} \mathrm{O}_{2}\right.$, UV/ozone), ${ }^{7}$ photocatalysis, ${ }^{8-10}$ or sonolysis and photocatalysis. ${ }^{11} \mathrm{~A}$ few studies looked at catalytic destruction of 1,4-dioxane, but most required the addition of high-energy resources such as UV light, ${ }^{12,13}$ ultrasonic waves, ${ }^{14}$ or electricity, ${ }^{15-17}$ which are not only costly from an energy perspective, but may also require the use of complicated reactor configurations and may not be suitable for universal treatment of 1,4-dioxane contamination (e.g. in chemical plumes).

"Dark" (non-photocatalytic) heterogeneous catalysis, which does not require additional energy sources, may be a more passive and more economically practical approach to treating 1,4-dioxane in water. Efforts have been made in the past to study the activation of chemical oxidants for AOP using materials as a heterogeneous form of Fenton's reagent, but few have focused much on 1,4-dioxane nor provided an experimental understanding of the surface chemistry. ${ }^{18,19} \mathrm{CuO}$ has been investigated using ozone as oxidant, and implicated Lewis acid sites for the decomposition of ozone. ${ }^{20} \mathrm{~A}$ Pd-based catalyst was reported effective for degrading 1,4-dioxane using peroxymonosulfate, and suggested surface-bound radicals were responsible for degradation. ${ }^{21}$ Two studies discussed using $\mathrm{H}_{2} \mathrm{O}_{2}$; one a titanosilicate zeolite that was slightly active in water at $60{ }^{\circ} \mathrm{C},{ }^{22}$ and another concerning $\mathrm{Fe}(\mathrm{II})$-containing clays that showed degradation activity on the order of several days. ${ }^{23}$ Unexplored for 1,4-dioxane degradation and other contaminants are a number of materials reported to be able to

\footnotetext{
${ }^{a}$ Department of Chemical and Biomolecular Engineering, Rice University, Houston, TX, School at Houston, Houston, TX, 77030, USA

${ }^{d}$ GSI Environmental, Houston, TX, 77098, USA

${ }^{e}$ Department of Chemistry, Houston, TX, 77005, USA

${ }^{f}$ Department of Civil and Environmental Engineering, Houston, TX, 77005, USA ${ }^{g}$ Department of Materials Science and Nano Engineering, Houston, TX, 77005, USA ${ }^{h}$ Center for Nano-Enabled Water Treatment, Rice University, Houston, TX, 77005, USA $\dagger$ Electronic supplementary information (ESI) available. See DOI: 10.1039/c9ra05007h
} 
nonphotocatalytically catalyze the dark dissociation of $\mathrm{H}_{2} \mathrm{O}_{2}$, such as $\mathrm{ZrO}_{2}{ }^{24}$ and $\mathrm{TiO}_{2} \cdot{ }^{25}$ Furthermore, any materials properties of these unconventional $\mathrm{H}_{2} \mathrm{O}_{2}$-active materials which allow them to degrade organics is unclear.

In this study, we screened commercially available relatively inexpensive metal oxide $\mathrm{H}_{2} \mathrm{O}_{2}$-active catalysts to establish a set of basic data for the degradation of aqueous-phase 1,4-dioxane using $\mathrm{H}_{2} \mathrm{O}_{2}$ at mild ambient conditions and in the dark. A 1,4dioxane degradation rate constant was measured for each material at room temperature and atmospheric pressure, and at near-neutral $\mathrm{pH} . \mathrm{H}_{2} \mathrm{O}_{2}$ consumption activity (quantified as a rate constant) and consumption efficiency (quantified as moles of 1,4-dioxane degraded per mole $\mathrm{H}_{2} \mathrm{O}_{2}$ consumed) were also determined. To understand the essential surface properties that direct the degradation process, we further analyzed the materials using in situ Fourier-transform infrared (FTIR) analysis of acid sites using pyridine, acid site poisoning catalytic tests using acetonitrile, and electron paramagnetic resonance (EPR). Based on these results, we proposed a reaction mechanism to explain the observed material-dependency of 1,4dioxane degradation.

\section{Materials}

$\mathrm{CuO}(>97 \%)$ and $\gamma-\mathrm{Al}_{2} \mathrm{O}_{3}(>97 \%)$ were used as received from Strem Chemicals. $\mathrm{ZrO}_{2}$ and $\mathrm{TiO}_{2} \mathrm{P} 25$ were obtained from Evonik. $\mathrm{Fe}_{2} \mathrm{O}_{3}$ (hydrated, catalyst grade 30-50 mesh, crushed prior to characterization and kinetic experiments), $\mathrm{WO}_{3}$ (nanopowder), Zeolite $\mathrm{Y}$ (hydrogen, $\left.30: 1 \mathrm{SiO}_{2}: \mathrm{Al}_{2} \mathrm{O}_{3}\right), \mathrm{CeO}_{2}(99.95 \%$, nanopowder), dichloromethane (chromasolv, 99.9\%), and 1,4dioxane ( $>99.5 \%), \mathrm{H}_{2} \mathrm{O}_{2}(30 \%)$, and $\mathrm{TiOSO}_{4}(\sim 15 \mathrm{wt} \%$ in dilute sulfuric acid) were used as received from Sigma Aldrich. A zirconia-supported tungsten oxide material (" $\mathrm{WO}_{x} / \mathrm{ZrO}_{2}$ ", $20 \mathrm{wt} \% \mathrm{WO}_{3}$ content) was obtained from MEI Chemicals and used as-received. Specific surface areas (SSA) of the metal oxide materials were evaluated on a Quantachrome Autosorb IIIB using five-point BET calculations on samples degassed at $350{ }^{\circ} \mathrm{C}$ overnight. 5-Tert-butoxycarbonyl-5-methyl-1-pyrroline- $N$-oxide (BMPO) was obtained from Enzo Life Sciences. Deionized water was used in all experiments.

\section{Analytical methods}

\subsection{Catalytic activity testing}

For kinetic experiments, $171 \mathrm{~mL}$ of deionized (DI) water, $0.4 \mu \mathrm{L}$ of 1,4-dioxane ([1,4-dioxane $\left.]_{0}=27 \mu \mathrm{M}, 2.3 \mathrm{ppm}\right)$, and 0-600 $\mu \mathrm{L}$ of $30 \% \mathrm{H}_{2} \mathrm{O}_{2}\left(\left[\mathrm{H}_{2} \mathrm{O}_{2}\right]_{0}=0-30 \mathrm{mM}\right)$ were added to a $250 \mathrm{~mL}$ Boston round bottle. After stirring, a $\sim 2 \mathrm{~mL}$ aliquot was taken from the reactor for baseline measurements of $\mathrm{H}_{2} \mathrm{O}_{2}$ and 1,4dioxane. The catalyst was added to the reactor, which was then sealed with a septum, covered in foil to shield from ambient light, and magnetically stirred at 600 RPM. The amount of added catalyst was chosen such that the total exposed oxide surface area in the reaction medium was the same between experiments ( $475 \mathrm{~m}^{2}$ per L-fluid, Table $\left.\mathrm{S} 1 \dagger\right)$. Aliquots $(\sim 1.5 \mathrm{~mL})$ of reaction fluid were filtered with a $0.2 \mu \mathrm{m}$ syringe filter to remove solid catalyst prior to $\mathrm{H}_{2} \mathrm{O}_{2}$ and 1,4-dioxane concentration measurements. Each reaction was repeated three times. No degradation was observed in experiments where only 1,4-dioxane and catalyst were present.

Because of order-of-magnitude differences in initial concentrations, the disappearance of $\mathrm{H}_{2} \mathrm{O}_{2}$ and 1,4-dioxane were both modeled as pseudo-first order processes, where the rate of disappearance of reactant $\mathrm{X}$ (either $\mathrm{H}_{2} \mathrm{O}_{2}$ or 1,4-dioxane), $r_{\mathrm{X}}$, is given by

$$
r_{\mathrm{X}}=\frac{\mathrm{dX}}{\mathrm{d} t}=k_{\text {meas }, \mathrm{X}} C_{\mathrm{X}}
$$

where $t$ is time, $C_{\mathrm{X}}$ is the concentration of reactant $\mathrm{X}$, and $k_{\text {meas, } \mathrm{X}}$ is the measured pseudo-first order rate constant, which can be found from integrating eqn (1) to obtain

$$
\ln \left(\frac{C_{\mathrm{X}}}{C_{\mathrm{X}, 0}}\right)=-k_{\text {meas }, \mathrm{X}} t
$$

where $C_{\mathrm{X}, 0}$ is the initial concentration of the reactant.

In order to better compare intrinsic catalytic activity, we report the pseudo-first order rate constant normalized by added catalyst surface area for each reagent for each catalyst, $k_{\mathrm{X}}$, since only exposed catalyst sites should be active. $k_{\mathrm{X}}$ is given by

$$
k_{\mathrm{X}}=\frac{k_{\text {meas }, \mathrm{X}}}{C_{\mathrm{cat}}}
$$

where $C_{\text {cat }}$ is the concentration of catalyst surface area in the reactor (units of $\mathrm{m}^{2} \mathrm{~mL}^{-1}$ ), given by eqn (4)

$$
C_{\text {cat }}=\frac{\mathrm{SSA}_{\text {cat }} g_{\text {cat }}}{V_{\text {reactor }}}
$$

where $\mathrm{SSA}_{\text {cat }}$ is the specific surface area of the catalyst (units $\mathrm{m}^{2}$ $\mathrm{g}^{-1}$, as determined by BET, see Table S1 $\dagger$ ), $g_{\text {cat }}$ is the grams catalyst added to the reactor (Table S1 $\dagger$ ), and $V_{\text {reactor }}$ is the liquid reaction volume.

Selective site poisoning experiments were conducted using acetonitrile (which can chemisorb onto Lewis acid sites ${ }^{26}$ ), in which the catalysts were premixed with $318 \mu \mathrm{L}$ of $0.1 \mathrm{M}$ acetonitrile stock solution (final [acetonitrile] in reactor $=186 \mu \mathrm{M}$ ). ${ }^{27}$ Residual activity is defined as

$$
\text { residual } k=\frac{k_{\text {no acetonitrile }}}{k_{\text {acetonitrile }}} \times 100 \% \text {. }
$$

\section{2 $\quad \mathrm{H}_{2} \mathrm{O}_{2}$ quantification}

$\mathrm{H}_{2} \mathrm{O}_{2}$ remaining in the aliquots was quantified using titanium oxysulfate $\left(\mathrm{TiOSO}_{4}, \sim 15\right.$ wt $\%$ in dilute $\left.\mathrm{H}_{2} \mathrm{SO}_{4}\right)$. TiOSO $\mathrm{S}_{4}$ reacts with $\mathrm{H}_{2} \mathrm{O}_{2}$ to form the yellow-colored product perititanic acid, quantifiable using UV-vis. ${ }^{28} \mathrm{~A}$ standard curve was made using $0-$ $80 \mu \mathrm{M} \mathrm{H}_{2} \mathrm{O}_{2}$ to verify that the response was linear at the maximum extinction (at $\lambda=405 \mathrm{~nm}$ ). Reaction samples were diluted up to $20 \times$ to verify that absorbance at $\lambda=405 \mathrm{~nm}$ was in the standard.

\subsection{1,4-Dioxane quantification}

The concentration of 1,4-dioxane was determined as detailed by Li et al. ${ }^{29}$ Briefly, $0.5 \mathrm{~mL}$ of reaction aliquot and $0.5 \mathrm{~mL}$ of 
dichloromethane (DCM) was added to an autosampler vial and vigorously shaked for at least 30 seconds to extract the 1,4dioxane into the DCM phase. Following freezing at $-20{ }^{\circ} \mathrm{C}$ for at least 1 hour, the liquid DCM was decanted from the vial and put into a fresh autosampler vial containing $\sim 10 \mathrm{mg}$ of sodium sulfate to sequester any residual water. These samples were then analyzed via GC-MS. A calibration curve was prepared using this method with 0-3200 ppb 1,4-dioxane in deionized water.

\subsection{Determination of mass transfer resistances}

To ensure the reported rate constants were kinetically limited, we evaluated external mass transfer resistances as we have done previously. ${ }^{30,31}$ We note that in this system, there is no gas phase reactants, therefore $k_{\mathrm{gl}}$ was neglected. Fig. $\mathrm{S} 1, \dagger$ prepared using $\mathrm{CuO}$, one of the most active catalysts for $\mathrm{H}_{2} \mathrm{O}_{2}$ degradation, shows a linear increase in the measured rate constant with added catalyst, indicating there were no external mass transfer limitations in this range. The circled point corresponds to the SSA loading chosen for all other reactions.

To assess any internal mass transfer resistances, we determined the Weisz-Prater criterion $\left(C_{\mathrm{WP}}\right)$ for both the first-order degradation of $\mathrm{H}_{2} \mathrm{O}_{2}$ and 1,4-dioxane according to ${ }^{32,33}$

$$
C_{\mathrm{WP}}=\frac{k^{\prime} \rho_{\mathrm{c}} R^{2}}{D_{\mathrm{e}}}
$$

where $k^{\prime}$ is the catalyst mass normalized rate constant $\left(\mathrm{m}^{3} \mathrm{~s}^{-1}\right.$ $\left.\mathrm{g}_{\text {cat }}{ }^{-1}\right), \rho_{\mathrm{c}}$ is the catalyst density $\left(\mathrm{g} \mathrm{m}^{-3}\right), R$ is the pellet radius (m, conservatively assumed to be $1 \mathrm{~mm}$ for all catalysts), and $D_{\mathrm{e}}$ is the effective diffusivity of $\mathrm{H}_{2} \mathrm{O}_{2}$ and 1,4-dioxane in the pores (assumed to be equivalent to $\mathrm{H}_{2} \mathrm{O}_{2}$ and 1,4-dioxane diffusivity in water, $5.0 \times 10^{-6} \mathrm{~m}^{2} \mathrm{~h}^{-1}$ and $6.0 \times 10^{-8} \mathrm{~m}^{2} \mathrm{~h}^{-1}$ respectively). As shown in Table $\mathbf{S} 2, \dagger$ the Weisz-Prater criterion was less than one for all materials, which implies that the catalysts' activities were not limited by internal diffusion.

\subsection{EPR experiments}

For the spin-trap experiments, $4 \mathrm{mM}$ of $\mathrm{CuO}, \mathrm{WO}_{x} / \mathrm{ZrO}_{2}$, or $\mathrm{ZrO}_{2}$ was added to a s $83 \mathrm{mM} \mathrm{H}_{2} \mathrm{O}_{2}$ and 5-10 mM BMPO solution, then mixed for $\sim 2 \mathrm{~min}$. Transient radical species rapidly react with BMPO, forming stable adducts..$^{34-37} 15 \mu \mathrm{L}$ of the reaction mixture was sampled and sealed with Critoseal. EPR spectra of the spin trapped radicals were obtained using a Bruker EMX spectrometer at room temperature. EPR measurements were taken using a frequency of $9.30 \mathrm{GHz}$, power of $20 \mathrm{~mW}$, modulation frequency of $100 \mathrm{kHz}$, modulation amplitude of $0.1 \mathrm{G}$, and time constant of $0.33 \mathrm{~s}$. No radicals were detected in control solutions without metal oxide.

Freeze trapping was also attempted for direct detection of radicals. In these experiments, the $5 \mathrm{~mm}$ o.d. EPR tubes were rapidly frozen in an EtOH/dry ice bath before transferring into liquid $\mathrm{N}_{2}$. The measurements were conducted at $115 \mathrm{~K}$ using a frequency of $9.28 \mathrm{GHz}$; power of $1 \mathrm{~mW}$; modulation frequency of $100 \mathrm{kHz}$, modulation amplitude of $2 \mathrm{G}$, and time constant of $0.33 \mathrm{~s}$.

\subsection{Pyridine-FTIR}

For the pyridine-FTIR experiments, the sample was pressed into a $13 \mathrm{~mm}$ diameter disk and analyzed in a homemade cell attached to a closed circulation system. Before pyridine adsorption, the cell was heated to $150{ }^{\circ} \mathrm{C}$ for $30 \mathrm{~min}$ at low pressure $\left(<10^{-3} \mathrm{~Pa}\right)$ then allowed to cool to $25{ }^{\circ} \mathrm{C}$. A spectrum was recorded as the background using a Bruker Tensor 27 FTIR spectrometer in transmittance mode. Gas-phase pyridine was then contacted with the sample for $\sim 20 \mathrm{~min}$, and then the chamber evacuated at $150{ }^{\circ} \mathrm{C}$ for $30 \mathrm{~min}$ at low pressure $(<1.0 \times$ $10^{-3} \mathrm{~Pa}$ ) to remove pyridine that was physically adsorbed before a FTIR spectrum of the chemisorbed pyridine was collected. Spectra were also taken after the sample was cooled to $25{ }^{\circ} \mathrm{C}$.

For experiments looking at both pyridine and water, gasphase water $(\sim 1 \mathrm{~atm})$ was added to the cell after the pyridine step. The water atmosphere was maintained for $\sim 20 \mathrm{~min}$ at $25{ }^{\circ} \mathrm{C}$ and then desorbed at $25{ }^{\circ} \mathrm{C}$ and $150{ }^{\circ} \mathrm{C}$. The sample was brought to $25^{\circ} \mathrm{C}$, and an additional spectrum collected.

The Lewis acid site concentration is given by ${ }^{38}$

$$
C_{\text {Lewis }}=\frac{1.42 \times I \times R^{2}}{W}
$$

where $C_{\text {Lewis }}$ is Lewis acid site concentration ( $\mathrm{mmol} \mathrm{g}_{\text {catalyst }}{ }^{-1}$ ), $R$ is the catalyst radius $(\mathrm{cm}), I$ is the integration of the Lewis band $\left(\mathrm{cm}^{-1}\right), W$ is the weight of disk $(\mathrm{mg})$, and the factor 1.42 $\mathrm{mol} \mathrm{cm} \mathrm{cm}^{-1}$ is the extinction coefficient of pyridine adsorbed to an acid site. ${ }^{38}$ The $W$ used for the experiments for $\mathrm{CuO}, \mathrm{ZrO}_{2}$, and $\mathrm{WO}_{x} / \mathrm{ZrO}_{2}$ were $4.17,27.2$, and $39.5 \mathrm{mg}$ respectively, and the $I$ were found to be $1.095,4.173$, and $17.317 \mathrm{~cm}^{-1}$ respectively.

\section{Results and discussion}

Fig. 1a shows the dark catalytic activities for $\mathrm{H}_{2} \mathrm{O}_{2}$ consumption alone (without 1,4-dioxane). $\mathrm{CeO}_{2}, \mathrm{Fe}_{2} \mathrm{O}_{3}$, and $\mathrm{CuO}$ all have high reaction rate constants, which generally agree with reported values of these Fenton-like materials, i.e., those that activate $\mathrm{H}_{2} \mathrm{O}_{2}$ via formal oxidation/reduction of the metal sites. ${ }^{25,39}$ The exception is $\mathrm{CuO}$, which was slower than other reports (Table $\mathrm{S} 3 \dagger)$, which may be due to differences in catalyst and $\mathrm{H}_{2} \mathrm{O}_{2}$ concentrations between studies. $\mathrm{ZrO}_{2}$ and $\mathrm{TiO}_{2}$ showed $\mathrm{H}_{2} \mathrm{O}_{2}$ degradation ability, in agreement with previous reports. ${ }^{24,25,39-41}$ $\mathrm{SiO}_{2}$ and $\mathrm{Al}_{2} \mathrm{O}_{3}$ exhibited only trace activity (also in agreement with literature), ${ }^{25}$ as was the case with zeolite Y. Monometallic $\mathrm{WO}_{3}$ was also nearly inactive.

Fig. 1 b shows catalytic activities for the $\mathrm{H}_{2} \mathrm{O}_{2}$ consumption in the presence of 1,4-dioxane, and catalytic activity for 1,4dioxane degradation. We denote the "best" 1,4-dioxane degradation catalysts as those that quickly degrade 1,4-dioxane (high $k_{\text {diox }}$ ) while consuming low amounts of $\mathrm{H}_{2} \mathrm{O}_{2}$ (low $k_{\mathrm{H}_{2} \mathrm{O}_{2}}$ ), i.e., those closest to the lower right hand side of the semi-log $k$-by- $k$ plot. Catalytic activities for $\mathrm{H}_{2} \mathrm{O}_{2}$ consumption did not generally change in the presence of 1,4-dioxane (comparing Fig. 1a and b). Materials weakly active for $\mathrm{H}_{2} \mathrm{O}_{2}$ consumption $\left(\mathrm{Al}_{2} \mathrm{O}_{3}, \mathrm{SiO}_{2}\right.$, and $\mathrm{WO}_{3}$ ) consumed $\mathrm{H}_{2} \mathrm{O}_{2}$ more rapidly, except for zeolite $\mathrm{Y}$, which became less active; all these showed minimal 1,4-dioxane degradation ability. 

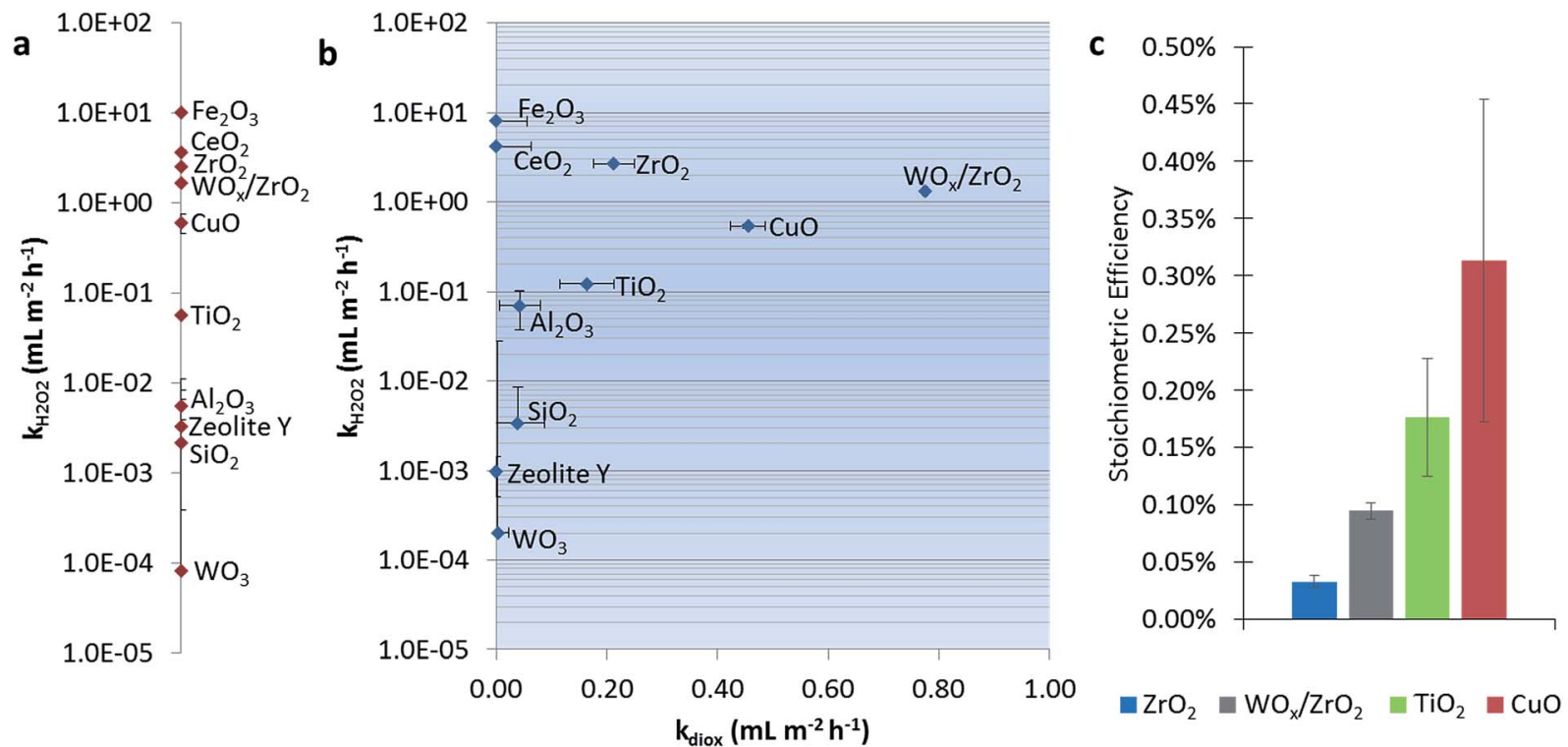

Fig. 1 Pseudo-first order rate constants normalized by catalyst surface area for $\mathrm{H}_{2} \mathrm{O}_{2}$ consumption $\left(\left[\mathrm{H}_{2} \mathrm{O}_{2}\right]_{0}=15 \mathrm{mM}\right.$, pH $\left.=6.5\right)$ in the (a) absence and (b) presence of 1,4-dioxane $\left([1,4 \text {-dioxane }]_{0}=27 \mu \mathrm{M}\right)$. Panel (b) shows the rate constant for $\mathrm{H}_{2} \mathrm{O}_{2}$ consumption plotted against the 1,4-dioxane degradation rate constant. (c) Stoichiometric efficiency (defined as moles 1,4-dioxane degraded per mole $\mathrm{H}_{2} \mathrm{O}_{2}$ consumed) calculated for catalysts active for 1,4-dioxane degradation at $10-12 \%$ conversion.

Catalysts most active for $\mathrm{H}_{2} \mathrm{O}_{2}$ consumption were not the most effective at degrading 1,4-dioxane; $\mathrm{Fe}_{2} \mathrm{O}_{3}$ and $\mathrm{CeO}_{2}$, the catalysts with the highest $k_{\mathrm{H}_{2} \mathrm{O}_{2}}$, were inactive for 1,4-dioxane, and could be due to the conversion of $\mathrm{H}_{2} \mathrm{O}_{2}$ to nonreactive species under these reaction conditions (neutral pH). Materials that had the highest $k_{\text {diox }}$ values were (listed in order of decreasing activity) $\mathrm{WO}_{x} / \mathrm{ZrO}_{2} \gg \mathrm{CuO}>\mathrm{ZrO}_{2} \gg \mathrm{TiO}_{2}$. Their $\mathrm{H}_{2} \mathrm{O}_{2}$ consumption activity was also less than those of $\mathrm{Fe}_{2} \mathrm{O}_{3}$ and $\mathrm{CeO}_{2}$.

We calculated the stoichiometric efficiency for the four catalysts most active for 1,4-dioxane degradation during the batch reactions (Fig. 1c). Under these conditions, $\mathrm{CuO}$ was the most $\mathrm{H}_{2} \mathrm{O}_{2}$-efficient, followed by $\mathrm{TiO}_{2}, \mathrm{WO}_{x} / \mathrm{ZrO}_{2}$, and $\mathrm{ZrO}_{2}$.
These values are on the same order of magnitude as those measured by Sedlak and co-workers for the degradation of phenol using $\mathrm{H}_{2} \mathrm{O}_{2}$ over a silica-Fe catalyst at neutral conditions $(\sim 0.20-0.30 \%){ }^{42,43} \mathrm{~A}$ direct comparison of these results to other materials is made with caution, as the initial reactant amount and reactant type $\left(50-250 \mathrm{mM} \mathrm{H}_{2} \mathrm{O}_{2}\right.$ and $0.5 \mathrm{mM}$ phenol $v s$. $15 \mathrm{mM} \mathrm{H}_{2} \mathrm{O}_{2}$ and $27 \mu \mathrm{M}$ 1,4-dioxane) differ.

To further understand the surface mechanism, we explored the effects of initial $\mathrm{H}_{2} \mathrm{O}_{2}$ concentrations (1.5-30 mM) using a Langmuir-Hinshelwood-Hougen-Watson (LHHW) bimolecular surface reaction model, which assumes the two reactants $\left(\mathrm{H}_{2} \mathrm{O}_{2}\right.$ and 1,4-dioxane) compete to adsorb to the same catalytic sites. The rate of $\mathrm{H}_{2} \mathrm{O}_{2}$ consumption $\left(\mathrm{r}^{\prime}{ }_{\mathrm{H}_{2} \mathrm{O}_{2}}\right)$ increased before
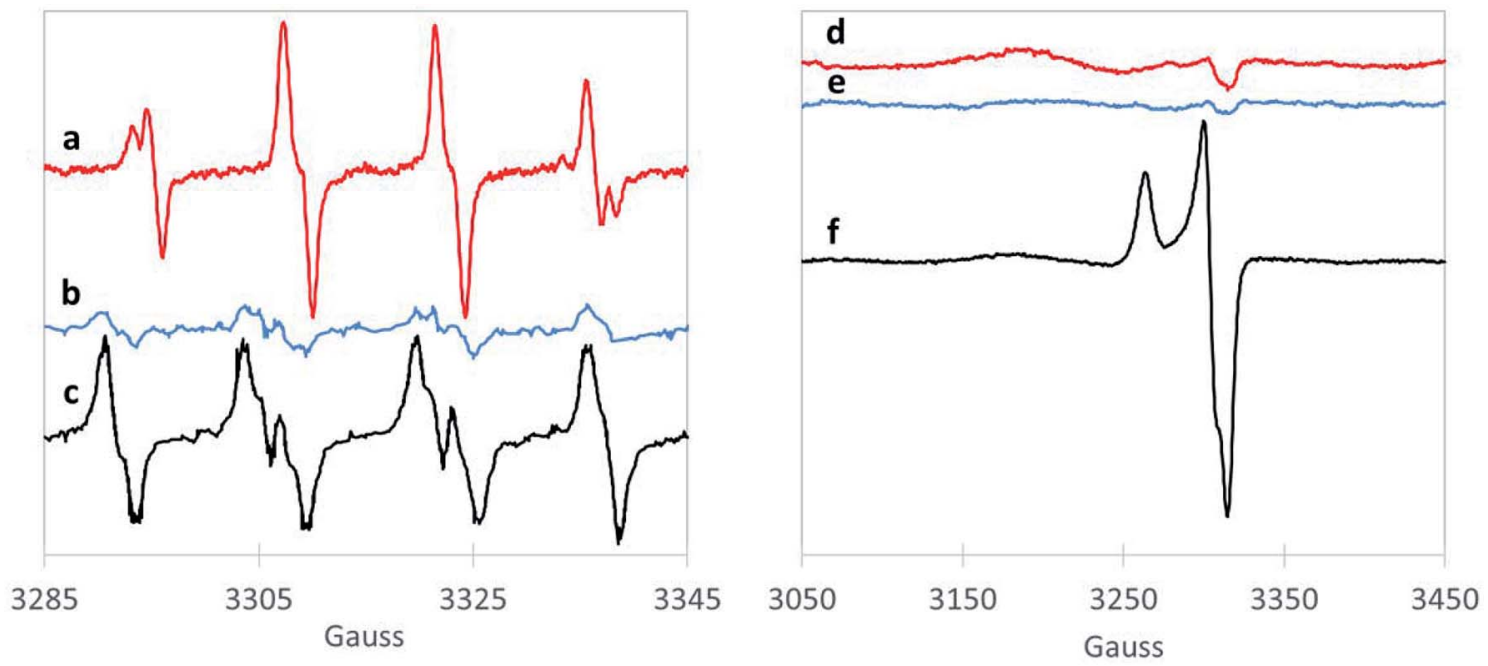

Fig. 2 BMPO-trapping of radical species in the $\mathrm{H}_{2} \mathrm{O}_{2}$ consumption with (a) $\mathrm{CuO}$ (red), (b) $\mathrm{ZrO}_{2}$ (blue) and (c) $\mathrm{WO}_{x} / \mathrm{ZrO} 2$ (black). Spectra following freeze trapping over (d) $\mathrm{CuO}$ (red), (e) $\mathrm{ZrO}_{2}$ (blue) and (f) $\mathrm{WO}_{x} / \mathrm{ZrO}_{2}$ (black). The small features at $3320 \mathrm{G}$ for traces (d) and (e) are artifacts from the EPR sample cavity. 

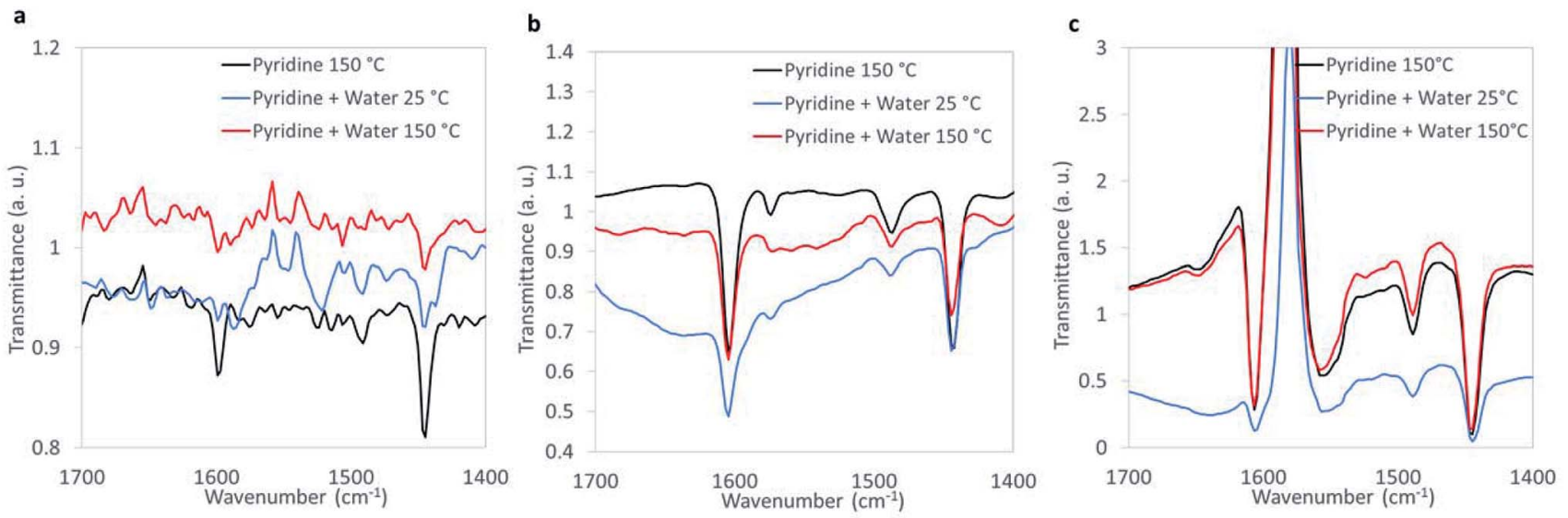

Fig. 3 FTIR spectra of chemisorbed pyridine under dehydrated and humid conditions for (a) $\mathrm{CuO}$, (b) $\mathrm{ZrO}_{2}, \mathrm{and}(\mathrm{c}) \mathrm{WO}_{x} / \mathrm{ZrO}_{2}$.

plateauing at high $\left[\mathrm{H}_{2} \mathrm{O}_{2}\right]_{0}$ for $\mathrm{WO}_{x} / \mathrm{ZrO}_{2}, \mathrm{CuO}$, and $\mathrm{ZrO}_{2}$, which was indicative of saturation coverage of the active sites at high $\mathrm{H}_{2} \mathrm{O}_{2}$ concentrations (Fig. S2a $\dagger$ ). The 1,4-dioxane degradation rate $\left(r_{1,4-\text { dioxane }}^{\prime}\right)$, however, also increased and remained pseudofirst order with respect to $\left[\mathrm{H}_{2} \mathrm{O}_{2}\right]$ (Fig. $\mathrm{S} 2 \mathrm{~b} \dagger$ ), which suggests that 1,4-dioxane adsorption (and subsequent reaction) sites are not blocked at high $\mathrm{H}_{2} \mathrm{O}_{2}$ concentrations, and implies that the adsorption and reaction occurs on sites different from those for $\mathrm{H}_{2} \mathrm{O}_{2}$ adsorption/reaction (for $\mathrm{WO}_{x} / \mathrm{ZrO}_{2}, \mathrm{CuO}$, and $\mathrm{ZrO}_{2}$ ).

We also examined the radicals formed from $\mathrm{H}_{2} \mathrm{O}_{2}$ activation by the 1,4-dioxane-active catalysts. Although EPR does not necessarily provide direct evidence of surface generation of radicals, it can reveal what radicals are generated in solution with the use of the spin-trap reagent. BMPO, the spin-trap reagent used here, rapidly reacts with otherwise transient radicals to form stable radical adducts with ${ }^{\circ} \mathrm{OH}$ and ${ }^{\circ} \mathrm{O}_{2}{ }^{-}$ species. The hyperfine structures of the BMPO adduct are characteristic of those of $\mathrm{BMPO} /{ }^{\circ} \mathrm{OH}$ (Fig. 2a), which fit well with two conformers with similar hyperfine splittings due to the nitrogen, the $\beta$ hydrogen, and one of the $\gamma$ hydrogen atoms, ${ }^{35,44}$

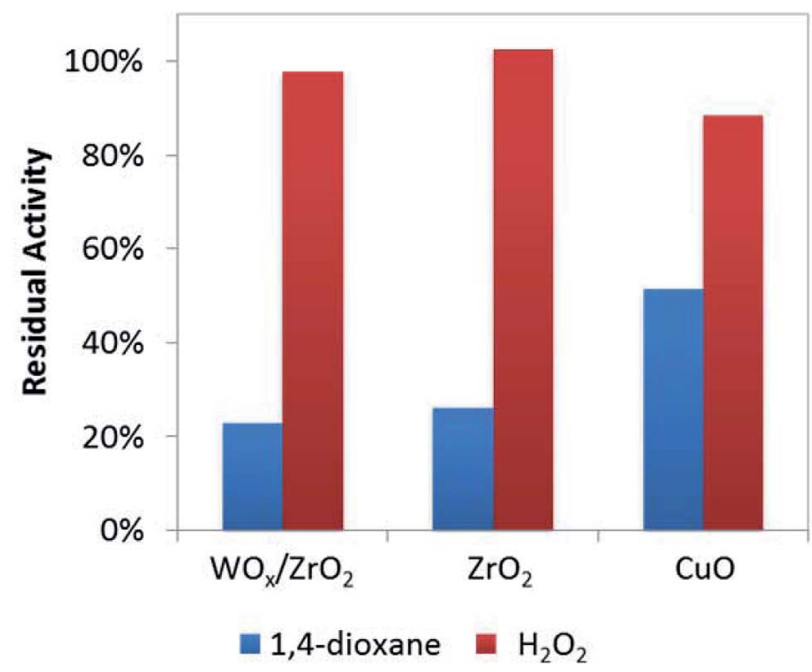

Fig. 4 Residual activity of catalysts for 1,4-dioxane and $\mathrm{H}_{2} \mathrm{O}_{2}$ degradation with the addition of 0.125 moles acetonitrile per mole surface site (186 $\mu \mathrm{M}$ acetonitrile). indicating formation of ${ }^{\circ} \mathrm{OH}$ radical over $\mathrm{CuO}$. The EPR signal did not change with the addition of superoxide dismutase ("SOD," an enzyme which rapidly and selectively converts ${ }^{\circ} \mathrm{O}_{2}{ }^{-}$ to $\mathrm{O}_{2}$ or $\mathrm{H}_{2} \mathrm{O}_{2}$ ), confirming that $\mathrm{CuO}$ did not generate ${ }^{\circ} \mathrm{O}_{2}{ }^{-}$ (Fig. S3 $\uparrow$ ). This is in contrast to a recent study using ozone to degrade 1,4-dioxane over $\mathrm{CuO}$, which formed primarily superoxide radical. ${ }^{20}$ However, as hydroxyl radical is amongst the strongest oxidants (Table S4 $\dagger$ ), it is likely responsible for the high 1,4-dioxane degradation ability of CuO.

The spectra of BMPO-radical adducts were significantly different when $\mathrm{ZrO}_{2}$ catalysts were exposed to $\mathrm{H}_{2} \mathrm{O}_{2}$ (Fig. 2b). The hyperfine structures of the EPR spectrum (Fig. 2b) indicates the formation of $\mathrm{BMPO} /{ }^{\circ} \mathrm{O}_{2}{ }^{-35} \mathrm{BMPO} /{ }^{\circ} \mathrm{O}_{2}{ }^{-}$adduct was also observed in the reaction of $\mathrm{WO}_{x} / \mathrm{ZrO}_{2}$ (Fig. 2c) and the spectrum fit well with two conformers with similar hyperfine splittings due to the nitrogen and the $\beta$ hydrogen atoms (Fig. S4a and $b \dagger$ ). Moreover, addition of SOD significantly decreased the amount of BMPO-trapped radical (Fig. S3†), corroborating that superoxide is the primary radical generated by $\mathrm{ZrO}_{2}$ from $\mathrm{H}_{2} \mathrm{O}_{2}$. This observation is consistent with a previous work..$^{45}$

Superoxide radicals have a lower oxidation potential compared to $\mathrm{H}_{2} \mathrm{O}_{2}{ }^{46,47}$ (Table $\mathrm{S} 3 \uparrow$ ), and are considered relatively unreactive..$^{48}$ It is surprising that this species (and not ${ }^{\circ} \mathrm{OH}$ ) is generated by $\mathrm{WO}_{x} / \mathrm{ZrO}_{2}$, the most active catalyst tested for 1,4dioxane degradation. This suggests some catalytically beneficial feature of $\mathrm{ZrO}_{2}$-supported $\mathrm{WO}_{x}$ domains that is absent from $\mathrm{ZrO}_{2}$ and from $\mathrm{WO}_{3}$. Direct freeze-trapping EPR measurements, in which $\mathrm{H}_{2} \mathrm{O}_{2}$ /metal oxide suspensions are frozen and analyzed for any generated radicals (without using a spin-trap reagent), showed signals for superoxide radicals for $\mathrm{WO}_{x} / \mathrm{ZrO}_{2}$ (Fig. 2f). The $g_{\mathrm{x} / \mathrm{y}}=2.007(3305 \mathrm{G})$ and $g_{\mathrm{z}}=2.088$ (broad peak centered at $3177 \mathrm{G}$ ) are typical of superoxide anion radicals in solution. The narrow peak at $3263 \mathrm{G}\left(g_{\mathrm{z}}=2.032\right)$ and trough at $3315 \mathrm{G}\left(g_{\mathrm{xy}}=\right.$ 2.002) are likely due to a $\mathrm{WO}_{x} / \mathrm{ZrO}_{2}$ surface-bound peroxyl radical whose $g$ values, particularly $g_{z}$, are perturbed due to its binding to the surface of the catalyst and much less spin-orbit coupling than that of free superoxide radical. ${ }^{49}$ The EPR spectrum can be fit well with a combination of these two types of radicals (Fig. S4c $\dagger$ ). No signals were detected in freeze-trapping of $\mathrm{ZrO}_{2}$ and $\mathrm{H}_{2} \mathrm{O}_{2}$ even though ${ }^{\circ} \mathrm{O}_{2}{ }^{-}$was spin-trapped using 


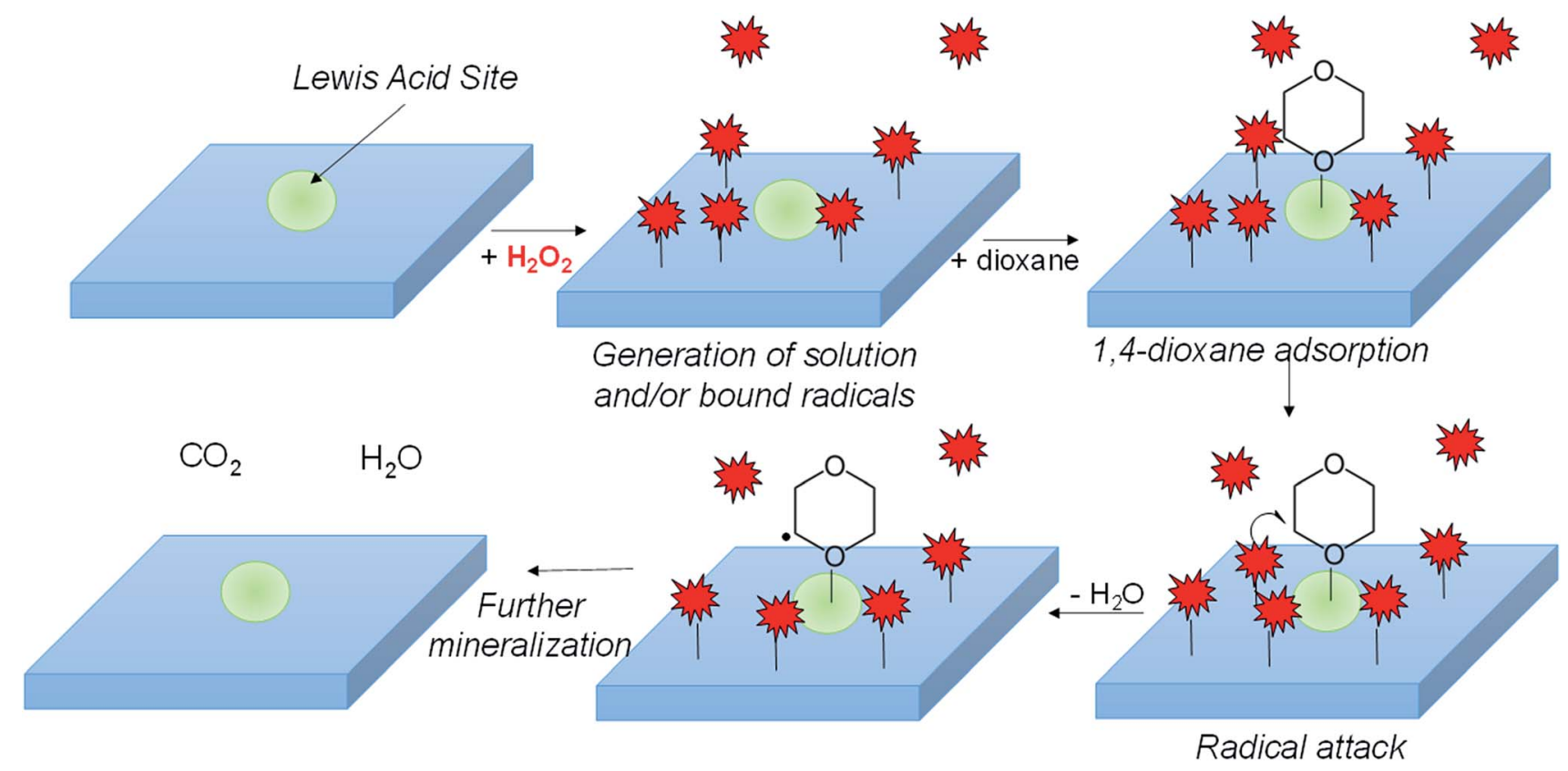

Scheme 1 Hypothesized general mechanism of 1,4-dioxane degradation over Lewis-acidic catalyst surfaces. 1,4-dioxane adsorbed to Lewis acid sites reacts with radicals generated from activation of $\mathrm{H}_{2} \mathrm{O}_{2}$ on surface.

BMPO in the same reaction, suggesting that $\mathrm{WO}_{x} / \mathrm{ZrO}_{2}$ can better stabilize ${ }^{\circ} \mathrm{O}_{2}{ }^{-}$radicals compared to $\mathrm{ZrO}_{2}$. In the $\mathrm{CuO}$ reaction with $\mathrm{H}_{2} \mathrm{O}_{2}$, the formation of ${ }^{\circ} \mathrm{OH}$ was too transient to be directly freeze-trapped.

Recognizing that 1,4-dioxane was historically used as a CVOC stabilizer due to its ability to complex with $\mathrm{AlCl}_{3}$ formed from CVOC storage inside aluminum-lined containers, ${ }^{50,51}$ we hypothesized that Lewis acid sites of the metal oxides are important for 1,4-dioxane degradation. We performed FTIR analysis of 1,4-dioxane-active materials using pyridine as probe molecule for surface acid sites under dry as well as humid conditions to simulate the aqueous-phase conditions of the oxidation reaction.

Characteristic peaks at $\sim 1445 \mathrm{~cm}^{-1}$ assigned to pyridine adsorbed on Lewis acid sites were observed on $\mathrm{WO}_{x} / \mathrm{ZrO}_{2}, \mathrm{ZrO}_{2}$, and $\mathrm{CuO}$ (Fig. 3). The concentration of Lewis acid sites was quantified by integrating the area of the $1445 \mathrm{~cm}^{-1}$ peak, then normalizing by the amount of catalytic material and using an extinction coefficient previously determined by Emeis $^{38}$ (Table $\mathrm{S} 5 \dagger$ ). The metal oxides had similar Lewis acid site densities, which were lower than the theoretical metal site density of $\sim 4$ atoms per $\mathrm{nm}^{-2}$ (roughly $15-20 \%$ ). ${ }^{52-54}$

To help verify these Lewis acid sites participate in 1,4dioxane oxidation catalysis, we co-added acetonitrile to the batch reactor tests (at amount equivalent to $\sim 12.5 \%$ of theoretical metal site density, Fig. 4) and quantified the resulting rate constants. As a water-soluble Lewis base (less basic but easier to handle compared to pyridine), acetonitrile lowered 1,4dioxane degradation substantially (by $\sim 75-80 \%$ ) over $\mathrm{ZrO}_{2}$ and $\mathrm{WO}_{x} / \mathrm{ZrO}_{2}$, but did not affect $\mathrm{H}_{2} \mathrm{O}_{2}$ consumption much (by $<5 \%$ ) (Fig. 4). The Lewis acid sites of $\mathrm{ZrO}_{2}$ and $\mathrm{WO}_{x} / \mathrm{ZrO}_{2}$ are the likely adsorption sites for 1,4-dioxane (as poisoned by acetonitrile). Acetonitrile inhibited 1,4-dioxane degradation over $\mathrm{CuO}$ to a lesser extent $(\sim 48 \%)$ and $\mathrm{H}_{2} \mathrm{O}_{2}$ consumption to a greater extent $(\sim 13 \%)$.

Humidification, which more closely resembles the aqueous reaction conditions, was introduced during FTIR analysis (Fig. 3). The introduction of water led to the appearance of Brønsted peaks (identified by characteristic pyridine IR peak at $\sim 1550 \mathrm{~cm}^{-1}$ ) on $\mathrm{CuO}$ but not $\mathrm{ZrO}_{2}$ or $\mathrm{WO}_{x} / \mathrm{ZrO}_{2}$. We suggest that $\mathrm{CuO}$, when in water, contains Brønsted acid sites that may contribute 1,4-dioxane degradation, and that Brønsted acidity may not be an important characteristic for $\mathrm{ZrO}_{2}$ or $\mathrm{WO}_{x} / \mathrm{ZrO}_{2}$ catalysis.

In combining the kinetic, EPR, FTIR, and surface poisoning results, we propose $\mathrm{H}_{2} \mathrm{O}_{2}$ dissociates onto metal surface sites into either surface adsorbed ${ }^{\circ} \mathrm{OH}$ or ${ }^{\circ} \mathrm{O}_{2}{ }^{-}$over the metal oxide surface, while Lewis-acidic sites (a minority of total sites) adsorb 1,4-dioxane (Scheme 1). The adsorbed radicals, or peroxyl radicals, react with adsorbed 1,4-dioxane, which contributes to more efficient use of $\mathrm{H}_{2} \mathrm{O}_{2}$ and to higher 1,4-dioxane degradation activity.

\section{Conclusions}

In this work, we surveyed a number of $\mathrm{H}_{2} \mathrm{O}_{2}$-active metal oxide materials, and evaluated their efficacy for the aqueous catalytic degradation of 1,4-dioxane at mild conditions (ambient temperature, neutral $\mathrm{pH}$, in the dark). Of the materials screened, we found that $\mathrm{WO}_{x} / \mathrm{ZrO}_{2}$ had the highest 1,4-dioxane degradation rate, followed by $\mathrm{CuO}$ and $\mathrm{ZrO}_{2}$. A LHHW analysis indicated that $\mathrm{H}_{2} \mathrm{O}_{2}$ and 1,4-dioxane adsorb to distinct catalytic sites. EPR measurements indicate that $\mathrm{CuO}$ activates $\mathrm{H}_{2} \mathrm{O}_{2}$ into highly reactive hydroxyl radicals, while $\mathrm{ZrO}_{2}$ and $\mathrm{WO}_{x} / \mathrm{ZrO}_{2}$ form solely less-active superoxide radicals. Pyridine-FTIR and selective poisoning experiments imply that 1,4-dioxane, a weak 
Lewis base, selectively adsorbs to Lewis acid sites on the catalysts. We present a possible surface-reaction mechanism in which 1,4-dioxane adsorbs to catalyst sites and reacts with metal-oxide supported radical species. These materials show promise for treatment of 1,4-dioxane contaminated waters.

\section{Conflicts of interest}

There are no conflicts to declare.

\section{Acknowledgements}

This study was supported by the Strategic Environmental Research and Development Program (SERDP) award ER-2307 and NIH NS094535 (A.-L. T.). Additional support for the collaboration came from the CAS/SAFEA International Partnership Program for Creative Research Teams. We thank C. Newell of GSI Environmental, D. Bryant of Geocleanse Intl., and S. Mahendra, M. Myers, and P. Gedalanga of UCLA for helpful discussions. K. N. H. did the kinetic studies and BET analysis, and Y. W. and F. W. did the FTIR analyses. EPR analyses were conducted by G. W. and A. T. All authors contributed toward the manuscript.

\section{References}

1 T. K. Mohr, 1,4-Dioxane and other Solvent Stabilizers, San Jose, CA, June 14, 2001.

2 D. T. Adamson, S. Mahendra, K. L. Walker, S. R. Rauch, S. Sengupta and C. J. Newell, A Multisite Survey To Identify the Scale of the 1,4-Dioxane Problem at Contaminated Groundwater Sites, Environ. Sci. Technol. Lett., 2014, 1, 254-258.

3 R. H. Anderson, J. K. Anderson and P. A. Bower, Cooccurrence of 1,4-dioxane with trichloroethylene in chlorinated solvent groundwater plumes at US Air Force installations: Fact or fiction, Integr. Environ. Assess. Manage., 2012, 8, 731.

4 M. J. Zenker, R. C. Borden and M. A. Barlaz, Occurrence and treatment of 1,4-dioxane in aqueous environments, Environ. Eng. Sci., 2003, 20, 423.

5 T. Mohr, J. Stickney and W. Diguiseppi, Environmental investigation and remediation: 1, 4-dioxane and other solvent stabilizers, Environmental investigation and remediation: 1, 4-dioxane and other solvent stabilizers, 2010.

6 T. Sale, C. Newell, H. Stroo, R. Hinchee and P. Johnson, Regarding Management of Chlorinated Solvents in Soils and Groundwater, 2008.

7 M. Otto and S. Nagaraja, Treatment technologies for 1,4dioxane: Fundamentals and field applications, Remediat. J., 2007, 17, 81.

8 S. W. Lam, M. Hermawan, H. M. Coleman, K. Fisher and R. Amal, The role of copper(II) ions in the photocatalytic oxidation of 1,4-dioxane, J. Mol. Catal. A: Chem., 2007, 278, 152-159.

9 T. Vescovi, H. M. Coleman and R. Amal, The effect of pH on UV-based advanced oxidation technologies - 1,4-Dioxane degradation, J. Hazard. Mater., 2010, 182, 75-79.
10 H. Barndõk, D. Hermosilla, C. Han, D. D. Dionysiou, C. Negro and Á. Blanco, Degradation of 1,4-dioxane from industrial wastewater by solar photocatalysis using immobilized $\mathrm{NF}^{-\mathrm{TiO}_{2}}$ composite with monodisperse $\mathrm{TiO}_{2}$ nanoparticles, Appl. Catal., B, 2016, 180, 44-52.

11 A. Nakajima, M. Tanaka, Y. Kameshima and K. Okada, Sonophotocatalytic destruction of 1,4-dioxane in aqueous systems by HF-treated $\mathrm{TiO}_{2}$ powder, J. Photochem. Photobiol., A, 2004, 167, 75-79.

12 H.-S. Son, J.-K. Im and K.-D. Zoh, A Fenton-like degradation mechanism for 1,4-dioxane using zero-valent iron (Fe0) and UV light, Water Res., 2009, 43, 1457-1463.

13 H. Barndõk, L. Blanco, D. Hermosilla and Á. Blanco, Heterogeneous photo-Fenton processes using zero valent iron microspheres for the treatment of wastewaters contaminated with 1,4-dioxane, Chem. Eng. J., 2016, 284, 112-121.

14 M. A. Beckett and I. Hua, Enhanced sonochemical decomposition of 1,4-dioxane by ferrous iron, Water Res., 2003, 37, 2372-2376.

15 J. R. Jasmann, T. Borch, T. C. Sale and J. Blotevogel, Advanced Electrochemical Oxidation of 1,4-Dioxane via Dark Catalysis by Novel Titanium Dioxide $\left(\mathrm{TiO}_{2}\right)$ Pellets, Environ. Sci. Technol., 2016, 50, 8817-8826.

16 J. De Clercq, E. Van de Steene, K. Verbeken and M. Verhaege, Electrochemical oxidation of 1, 4-dioxane at boron-doped diamond electrode, J. Chem. Technol. Biotechnol., 2010, 85, 1162-1167.

17 J. Y. Choi, Y.-J. Lee, J. Shin and J.-W. Yang, Anodic oxidation of 1, 4-dioxane on boron-doped diamond electrodes for wastewater treatment, J. Hazard. Mater., 2010, 179, 762-768.

18 A. D. Bokare and W. Choi, Review of iron-free Fenton-like systems for activating $\mathrm{H}_{2} \mathrm{O}_{2}$ in advanced oxidation processes, J. Hazard. Mater., 2014, 275, 121-135.

19 S. Wu, H. He, X. Li, C. Yang, G. Zeng, B. Wu, S. He and L. Lu, Insights into atrazine degradation by persulfate activation using composite of nanoscale zero-valent iron and graphene: Performances and mechanisms, Chem. Eng. J., 2018, 341, 126-136.

20 A. Basso, R. Landers, P. J. J. Alvarez, G. L. Puma and R. F. P. M. Moreira, Treatment of aqueous solutions of 1,4dioxane by ozonation and catalytic ozonation with copper oxide (CuO) AU - Scaratti, Gidiane, Environ. Technol., 2018, 1-13.

21 Y. Feng, P.-H. Lee, D. Wu and K. Shih, Surface-bound sulfate radical-dominated degradation of 1,4-dioxane by aluminasupported palladium $\left(\mathrm{Pd} / \mathrm{Al}_{2} \mathrm{O}_{3}\right) \quad$ catalyzed peroxymonosulfate, Water Res., 2017, 120, 12-21.

22 W. Fan, Y. Kubota and T. Tatsumi, Oxidation of 1,4-Dioxane over Ti-MWW in the Presence of $\mathrm{H}_{2} \mathrm{O}_{2}$, ChemSusChem, 2008, 1, 175-178.

23 Q. Zeng, H. Dong, X. Wang, T. Yu and W. Cui, Degradation of 1, 4-dioxane by hydroxyl radicals produced from clay minerals, J. Hazard. Mater., 2017, 331, 88-98.

24 C. M. Lousada and M. Jonsson, Kinetics, Mechanism, and Activation Energy of $\mathrm{H}_{2} \mathrm{O}_{2}$ Decomposition on the Surface of $\mathrm{ZrO}_{2}$, J. Phys. Chem. C, 2010, 114, 11202-11208. 
25 A. Hiroki and J. A. LaVerne, Decomposition of Hydrogen Peroxide at Water-Ceramic Oxide Interfaces, J. Phys. Chem. B, 2005, 109, 3364-3370.

26 J. W. Harris, M. J. Cordon, J. R. Di Iorio, J. C. Vega-Vila, F. H. Ribeiro and R. Gounder, Titration and quantification of open and closed Lewis acid sites in Sn-Beta zeolites that catalyze glucose isomerization, J. Catal., 2016, 335, 141-154.

27 I. E. Wachs, C. R. Brundle and J. C. A. Evans, Characterization of Catalytic Materials, 2009.

28 C. N. Satterfield and A. H. Bonnell, Interferences in Titanium Sulfate Method for Hydrogen Peroxide, Anal. Chem., 1955, 27, 1174-1175.

29 M. Li, P. Conlon, S. Fiorenza, R. J. Vitale and P. J. J. Alvarez, Rapid Analysis of 1,4-Dioxane in Groundwater by Frozen Micro-Extraction with Gas Chromatography/Mass Spectrometry, Groundwater Monit. Rem., 2011, 31, 70-76.

30 Y.-L. Fang, K. N. Heck, P. J. J. Alvarez and M. S. Wong, Kinetics Analysis of Palladium/Gold Nanoparticles as Colloidal Hydrodechlorination Catalysts, ACS Catal., 2011, 1, 128-138.

31 H. Qian, Z. Zhao, J. C. Velazquez, L. A. Pretzer, K. N. Heck and M. S. Wong, Supporting palladium metal on gold nanoparticles improves its catalysis for nitrite reduction, Nanoscale, 2014, 6, 358-364.

32 P. B. Weisz and C. D. Prater, Interpretation of Measurements in Experimental Catalysis, in Advances in Catalysis, ed. W. G. Frankenburg, V. I. Komarewsky and E. K. Rideal, Academic Press, 1954, vol. 6, pp. 143-196.

33 N. Soultanidis, W. Zhou, A. C. Psarras, A. J. Gonzalez, E. F. Iliopoulou, C. J. Kiely, I. E. Wachs and M. S. Wong, Relating $n$-Pentane Isomerization Activity to the Tungsten Surface Density of $\mathrm{WO}_{x} / \mathrm{ZrO}_{2}, J$. Am. Chem. Soc., 2010, 132, 13462-13471.

34 B. Gopalakrishnan, K. M. Nash, M. Velayutham and F. A. Villamena, Detection of nitric oxide and superoxide radical anion by electron paramagnetic resonance spectroscopy from cells using spin traps, J. Visualized Exp., 2012, e2810.

35 H. Zhao, J. Joseph, H. Zhang, H. Karoui and B. Kalyanaraman, Synthesis and biochemical applications of a solid cyclic nitrone spin trap: a relatively superior trap for detecting superoxide anions and glutathiyl radicals, Free Radical Biol. Med., 2001, 31, 599-606.

36 H. Shi, G. Timmins, M. Monske, A. Burdick, B. Kalyanaraman, Y. Liu, J.-L. Clément, S. Burchiel and K. J. Liu, Evaluation of spin trapping agents and trapping conditions for detection of cell-generated reactive oxygen species, Arch. Biochem. Biophys., 2005, 437, 59-68.

37 D. Liu, Z. Xiu, F. Liu, G. Wu, D. Adamson, C. Newell, P. Vikesland, A.-L. Tsai and P. J. Alvarez, Perfluorooctanoic acid degradation in the presence of $\mathrm{Fe}(\mathrm{III})$ under natural sunlight, J. Hazard. Mater., 2013, 262, 456-463.

38 C. A. Emeis, Determination of Integrated Molar Extinction Coefficients for Infrared Absorption Bands of Pyridine Adsorbed on Solid Acid Catalysts, J. Catal., 1993, 141, 347354.
39 C. M. Lousada, M. Yang, K. Nilsson and M. Jonsson, Catalytic decomposition of hydrogen peroxide on transition metal and lanthanide oxides, J. Mol. Catal. A: Chem., 2013, 379, 178-184.

40 C. M. Lousada, A. J. Johansson, T. Brinck and M. Jonsson, Mechanism of $\mathrm{H}_{2} \mathrm{O}_{2}$ Decomposition on Transition Metal Oxide Surfaces, J. Phys. Chem. C, 2012, 116, 9533-9543.

41 C. M. Lousada, A. J. Johansson, T. Brinck and M. Jonsson, Reactivity of metal oxide clusters with hydrogen peroxide and water - a DFT study evaluating the performance of different exchange-correlation functionals, Phys. Chem. Chem. Phys., 2013, 15, 5539-5552.

42 A. L.-T. Pham, F. M. Doyle and D. L. Sedlak, Kinetics and efficiency of $\mathrm{H}_{2} \mathrm{O}_{2}$ activation by iron-containing minerals and aquifer materials, Water Res., 2012, 46, 6454-6462.

43 A. L.-T. Pham, C. Lee, F. M. Doyle and D. L. Sedlak, A SilicaSupported Iron Oxide Catalyst Capable of Activating Hydrogen Peroxide at Neutral pH Values, Environ. Sci. Technol., 2009, 43, 8930-8935.

44 P. Baldrian, V. Merhautová, J. Gabriel, F. Nerud, P. Stopka, M. Hrubý and M. J. Beneš, Decolorization of synthetic dyes by hydrogen peroxide with heterogeneous catalysis by mixed iron oxides, Appl. Catal., B, 2006, 66, 258-264.

45 E. Giamello, P. Rumori, F. Geobaldo, B. Fubini and M. Paganini, The interaction between hydrogen peroxide and metal oxides: EPR investigations, Appl. Magn. Reson., 1996, 10, 173-192.

46 J. O. M. Bockris and L. F. Oldfield, The oxidation-reduction reactions of hydrogen peroxide at inert metal electrodes and mercury cathodes, Trans. Faraday Soc., 1955, 51, 249259.

47 G. R. Buettner, The Pecking Order of Free Radicals and Antioxidants: Lipid Peroxidation, $\alpha$-Tocopherol, and Ascorbate, Arch. Biochem. Biophys., 1993, 300, 535-543.

48 J. Nordberg and E. S. J. Arnér, Reactive oxygen species, antioxidants, and the mammalian thioredoxin system1, Free Radical Biol. Med., 2001, 31, 1287-1312.

49 D. M. Murphy and E. Giamello, EPR of Paramagnetic Centres on Solid Surfaces, Electron Paramagn. Reson., 2002, 18, 183-221.

$50 \mathrm{~W}$. L. Archer, A laboratory evaluation of 1,1,1Trichloroethane-Metal-Inhibitor systems, Mater. Corros., 1984, 35, 60-69.

51 W. L. Archer, Aluminum-1, 1, 1-trichloroethane. Reactions and inhibition, Ind. Eng. Chem. Prod. Res. Dev., 1982, 21, 670-672.

52 T. Kim, A. Burrows, C. J. Kiely and I. E. Wachs, Molecular/ electronic structure-surface acidity relationships of modelsupported tungsten oxide catalysts, J. Catal., 2007, 246, 370-381.

53 I. E. Wachs, Raman and IR studies of surface metal oxide species on oxide supports: Supported metal oxide catalysts, Catal. Today, 1996, 27, 437-455.

54 W. V. Knowles, M. O. Nutt and M. S. Wong, Supported metal oxides and the surface density metric, in Handbook of Catalyst Synthesis: The Science and Engineering of Catalyst Preparation, ed. Regalbuto J. R., Taylor \& Francis, Boca Raton, FL, 2007, pp. 251-281. 